\title{
The Study of Interior Monologue in Houshang Golshiri's Shazdeh Ehtejab, Virginia Woolf's Two Selected Novels, Mrs. Dalloway and to the Lighthouse; A Comparative Study
}

\author{
Narges Raoufzadeh ${ }^{1}$, Fatemeh Sadat Basirizadeh ${ }^{2}$, Shahrzad Mohammad Hosein ${ }^{3}$ \\ ${ }^{I}$ Department of English Language and Literature, Science and Research Branch, Islamic Azad University, \\ Tehran, Iran. \\ ${ }^{2}$ Young Researchers and Elite Club, Qom Branch, Islamic Azad University, Qom, Iran. \\ ${ }^{3}$ Department of English Language and literature, North Tehran Branch, Islamic Azad University, Tehran, \\ Iran. \\ raufzadehn@gmail.com
}

\begin{abstract}
This paper aims to compare interior monologue which is a modern technique in three selected novels. Comparing Houshang Golshiri's Shazdeh Ehtejab with Virginia Woolf's Mrs. Dalloway and To the Lighthouse. Golshiri has made use of both direct and indirect interior monologues in his master piece, Shazdeh Ehtejab. An early example in Persian fiction which has a great emphasis on form and techniques of narrating the story. The present study will examine, in detail the creation of interior monologue through the minds of characters with reference to Golshiri's Shazdeh Ehtejab and Virginia Woolf's two selected novels, Mrs. Dalloway and To the Lighthouse. Focusing on the narrative techniques used by these two modernist writers and deals with illustrations from the novel and its explanations. The aim of this study is to show how Golshiri and Woolf try to move deeply into the character's consciousness. They use the narrative technique, Interior Monologue, in their novels that deals with the flow of ideas, thoughts, feelings, and sensation.
\end{abstract}

\section{Keywords}

interior monologue; modern technique; modernist; narrative technique

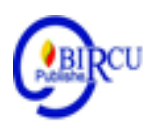

\section{Introduction}

Houshang Golshiri and Virginia Woolf are modernist writers. Modernist Literature captured the social and the historical ramification of late 19 and beginning of 20th century Europe through its content and form a narrative technique which is a great reaction of modernism that is against the value of realism in the Victorian period. It's a fiction writing technique that depicts feelings and thoughts of characters or human minds, and is applied by many novelists like James Joyce and Virginia Woolf. This literary movement often moves beyond the limitations of the realist novel with a concern for larger factors such as social and historical change, this is shown for example through the interior monologue (stream of consciousness). Golshiri and Woolf show new techniques to express a different point of view by regarding to the notion of time. Actions in the novels take place in a single day and during this single day, time is constantly flowing from present to past or to the future. The major moments of the novels constitute by flashbacks which being represented by the stream of consciousness technique. Golshiri and Woolf use the flashback techniques, which enables the reader to go from present to past or to future without having a chronological order. They use simple dialogues between the different characters and by using stream of consciousness technique, show feelings and thoughts of different characters. 


\section{Methodology}

A piece of writing expressing a character's inner thoughts, feelings and impressions. It's a narrative technique that exhibits the thoughts through the minds of protagonists. Interior monologue is often used interchangeably with stream of consciousness. Stream of consciousness is more general and encompassing a variety of techniques including interior monologue which maybe either direct or indirect. (1) Direct Interior Monologue: Presentation of consciousness in an uninterrupted way, from the first person point of view, without commentary or guidance from a third person narrator. In direct interior monologue, the writer gives direct access to those thoughts that a character is thinking about. (2) Indirect Interior Monologue: Presentation of a character's thoughts by a third person omniscient narrator who serves as presenter, selector, guide and commentator. By changing sentences from present to past and first person point of view to the third person point of view, direct thoughts become indirect thoughts. According to Abrams (1912-2015) stream of consciousness was a phrase used by William James in his Principles of Psychology (1890) to illustrate the unbroken flow of perceptions, memories, thoughts, and feelings in the waking mind; it has been applied to describe a narrative technique in modern fiction. Therefore, "stream of consciousness" is the name applied specifically to a mode of narration that assumes to reproduce the full range and continuous flow of a character's mental process, in which sense perceptions merge with conscious and half-conscious thoughts, memories, expectations, feelings and random associations (Glossary of Literary Terms p. 130)

\section{Discussion}

\subsection{Summary of Golshiri's Shazdeh Ehtejab}

Houshang Golshiri is an Iranian fiction writer, critic and editor who were born in Isfahan in 1937. He is known as one of the most influential writers of Persian prose of the twentieth century. He published his novel Shazdeh Ehtejab in 1974. Golshiri was awarded Germany's Erich Maria Remarque Prize in 1999 for his efforts to fight oppressions and promote democracy and human rights. Shazdeh Ehtejab (Prince Ehtejab) is Houshang Golshiri's first novel, published in 1969. The novel brought Golshiri significant fame. Shazdeh Ehtejab, who is the last surviving descendent of an aristocratic Qajar family, is the central character of the story. He has no heirs, has sold many of his possessions and is largely helpless. He is spending his last days alone, in the magnificent rooms of his glorious palace, sitting on a chair and suffers from tuberculosis, which he mentions as the hereditary fever of his family. Shazdeh is thinking about the past four generations of his family. The events happened to him personally or gleaned from books and photo albums.

He remembers the glory days of his ancestors as well as days of decadence and degradation. While he is reviewing and recollecting the old letters, finds how his cruel grandfather caused the death of his grandmother and murdered Shazdeh's mother and brother. Shazdeh is searching for his identity throughout the story of different characters, specially his wife, Fakhrounesa. Many of the characters who appear in the story are dead. Interior monologue from the perspective of Shazdeh is the primary technique Golshiri uses in this story that follows Shazdeh's stream of consciousness. It means many of the events in the story take place in the memories of Shazdeh. As Shazdeh remembers or hallucinates his way through the last day of his life, he is consumed by his familial history and his identity as the last member of his family. 


\section{Indirect Interior Monologue in Shazdeh Ehtejab}

The structure of the story is belonging and mixing with Shazdeh's memories. In Shazdeh Ehtejab, narrators change from one part to the other part of the story, sometimes the narrator is Fakhri, sometimes Fakhrounesa, sometimes Shazdeh and sometimes Golshiri himself. Changing the point of view is the important and main point in the text. Sometimes Fakhri is explaining a matter, then in the next paragraph Fakhrounesa describing the same matter. In fact, the story is narrating from different points of view, while all of them are passing through Shazdeh's mind. For example, on page 47 of the story the narrator is Shazdeh.

On page 76 while the writer is narrating the story, his sentences mixes with Fakhri's sentences and suddenly it changes and Fakhrounesa is narrating. These events happen and repeat in different parts of the story which make the story more interesting and unique. Golshiri uses other technique in that Fakhri and Fakhrounesa become one in some parts of the story. Shazdeh's room has been full of antique and old things, but now its empty. His room is an example of his mind, by remembering and reviewing, Shazdeh puts them aside and feels comfort. Shazdeh doesn't want to clean all equipment and pictures in the room. Want to forget them under the dust. Fakhri is a replacement for Fakhrounesa, Shazdeh wants to find a replacement for Fakhrounesa to forget her death.

\subsection{Summary of Virginia Woolf's Mrs. Dalloway}

Mrs. Dalloway, a unique novel by British novelist, Virginia Woolf, takes place in a single day, a Wednesday in mid-June 1923. The story covers from morning to night in Clarissa Dalloway, an upper-class house wife. Clarissa is preparing herself for her evening party, she decides to buy flower herself, so walks through her London neighborhood for buying flowers for the party. Throughout the morning, Clarissa is reviewing her past. She returns home from flower shopping and faces her old suitor Peter Walsh unexpectedly. Thirty years ago she married Richard Dalloway, a politician, rather than her suitor Peter Walsh. Peter asks Clarrisa about her life, weather she is happy with Richard or not, but before receiving any answer her daughter enters, so Peter leaves while he is thinking about Clarrisa refusal that still obsesses him. Then the point of view shifts to Septimus, who was injured in the first world war, and his Italian wife, Lucrezia. Septimus sees everything worthless in the England he fought for. His doctor Sir William plans to send him to a mental institution. Septimus jumps from a window, in order to avoid this fate. The whole story takes place in one day, from the opening scene in which Clarrisa goes out to buy flowers to her return home, eraly morning at 11:00 am through the end of the party, early night at 3:00 am. During the story Richard Dalloway tries to tell Clarrisa that he loves her. He returns home with a large bunch of roses, but unfortunately he isn't able to show all his feeling and never finds the words because it has been so long since he last said it. Sir William and Lady Bradshaw arrive very late into the party. They explain the reason for being late, as one of Sir William's patients, Septimus, had committed suicide. The party ends with Clarrisa disappointed at the success of her party.

\section{Indirect Interior Monologue in Virginia Woolf's Mrs. Dalloway.}

Woolf's Mrs. Dalloway is one of the great masterpieces which still manages to fascinate readers. Woolf uses indirect interior monologue, indirect quotation of a character's unvoiced thoughts through the third person narrator, to craft Mrs. Dalloway. The first nine sentences of the novel make it evident, how Woolf reproduced the character's thoughts 
directly and in a way that one would imagine the character is thinking, while the narrator continues to talk of the character in the third person.

Mrs. Dalloway said she would buy the flowers herself. For Lucy had her work cut out for her. The doors would be taken off their hinges; Rumpelmayer's men were coming. And then, thought Clarissa Dalloway, what a morning--fresh as if issued to children on a beach. What a lark! What a plunge! For so it had always seemed to her, when, with a little squeak of the hinges, which she could hear now, she had burst open the French windows and plunged at Bourton into the open air. How fresh, how calm, stiller than this of course, the air was in the early morning; like the flap of a wave; the kiss of a wave; chill and sharp and yet (for a girl of eighteen as she then was) solemn, feeling as she did, standing there at the open window, that something awful was about to happen; looking at the flowers, at the trees with the smoke winding off them and the rooks rising, falling; standing and looking until Peter Walsh said, "Musing among the vegetables?"--was that it?- -"I prefer men to cauliflowers"--was that it? He must have said it at breakfast one morning when she had gone out on to the terrace--Peter Walsh. He would be back from India one of these days, June or July. (Mrs Dalloway,5

Here Woolf created the favorable influence and effect of a narrator talking to a reader along with the effect that Clarissa Dalloway is talking to herself in the third person. But it remains unanswered "to whom?". The other example occurs when Clarrisa meets Peter, who she's been in love with, Peter explains his returning to London for the matter of divorce. Then we have Clarrisa's reaction to this statement. Woolf portrays beautifully.

Clarissa sat very upright; drew in her breath."I am in love," he said, not to her however, but to some one raised up in the dark so that you could not touch her but must lay your garland down on the grass in the dark. "In love," he repeated, now speaking rather dryly to Clarissa Dalloway; "in love with a girl in India." He had deposited his garland. Clarissa could make what she would of it. "In love!" she said. That he at his age should be sucked under in his little bowtie by that monster! And there's no flesh on his neck; his hands are red; and he's six months older than I am! her eye flashed back to her; but in her heart she felt, all the same, he is in love. He has that, she felt; he is in love (Mrs, Dalloway, 30).

Here Woolf illustrates Clarrisa's inner reactions that manage to bring female frustration and disappointment to life. On page 34 Woolf skillfully brings another example. This passage is written as if Peter were talking to himself, but it's again in the third person.

He was not old, or set, or dried in the least. As for caring what they said of him-the Dalloways, the Whitbreads, and their set, he cared not a straw--not a straw (though it was true he would have, sometime or other, to see whether Richard couldn't help him to some job). Striding, staring, he glared at the statue of the Duke of Cambridge. He had been sent down from Oxford--true. He had been a Socialist, in some sense a failure--true. Still the future of civilization lies, he thought, in the hands of young men like that; of young men such as he was, thirty years ago; with their love of abstract principles; getting books sent out to them all the way from London to a peak in the Himalayas; reading science; reading philosophy. The future lies in the hands of young men like that, he thought (Mrs Dalloway, 34).

\subsection{Summary of Virginia Woolf's To the Lighthouse}

To the Lighthouse is divided into three sections: "The Window", "Time Passes", and "The Lighthouse". The first section "The Window" opens just before starting the first world war. Mr.Ramsay, who is a philosopher, with his wife and his eight children are staying in their summer house in the Hebrides, an Island in the west part of Scotland. James Ramsay 
who is six years old wants to visit the lighthouse which is located across the bay, but his mother tells him if the weather permits, they will go there the next day. They host a number of guests such as Charles Tansley, Lily Briscoe, William Bankes, Paul Rayley and Minta Doyle. Lily begins her painting, Mrs Ramsay's portrait. Time passes and the novel enters into the second section very quickly. Ten years pass before the family returns to their summer house. War breaks out across Europe and Mrs Ramsay dies suddenly one night. Andrew Ramsay her oldest son is killed in a battle, and Prue her daughter dies due to childbirth. In the third section, "The Lighthouse" Mr Ramsay with James, who is now sixteen years old, takes a journey to the lighthouse, and Lily tries to complete a painting she started ten years ago on her last visit. As the boat reaches its destination, lily puts the finishing touch on her painting. She finally achieves her dream.

\section{Indirect Interior Monologue in Virginia Woolf's To The Lighthouse}

Although a third-person omniscient narrator tells the story moving in and out of multiple character's minds, Woolf's handling of point of view is further complicated by the fact that character's perspectives, especially their views on other characters, change frequently throughout the novel, sometimes within a paragraph or even a single sentence. Furthermore, a character's thoughts often flow into those of other characters, making it difficult sometimes for the reader to determine where one character's thoughts leave off and another character's begin. Virginia Woolf, among the stream-of-consciousness writers, relies most on the indirect interior monologue and she uses it with great skill. In To the Lighthouse Virginia Woolf succeeds in producing a much subtle effect through the use of this technique. This novel contains a great deal of straight, conventional narration and description, but the interior monologue is used often enough to give the novel its special character of seeming to be always within the consciousness of the chief characters.

For how would you like to be shut up for a whole month at a time, and possibly more in stormy weather, upon a rock the size of a tennis lawn? She would ask; and to have no letters and newspapers, and to see nobody; if you were married, not to see your wife, not to know how your children were, --if they were ill, if they had fallen down and broken their legs or arms; to see the same dreary waves breaking week after week, and then a dreadful storm coming, and the windows covered with spray, and birds dashed against the lamp, and the whole place rocking, and not be able to put your nose out of doors for fear of being swept into the sea? How would you like that? She asked, (To The Lighthouse.4)

The passage above is represented in the manner of straight narration by the author, but it is clearly what the character feels and thinks, and it reflects the character's consciousness and inner thought. In this passage, Woolf facilitates the indirect interior monologue with her unique skills.

I respect you (she addressed him silently) in every atom; you are not vain; you are entirely impersonal; you are finer than Mr. Ramsay; you are the finest human being that I know; you have neither wife nor child (without any sexual feeling, she longed to cherish that loneliness), you live for science (involuntarily, sections of potatoes rose before her eyes); praise would be an insult to you; generous, purehearted, heroic man! (To The Lighthouse, 18)

Here the parentheses signal sudden and momentary switches in perspective. The narrative is thrown backwards and forwards between Lily's voice, with its intonation mimicked exactly. Lily's dwelling on the austerity of Bankes' life indicates not only Bankes' desire for solitude, but also hers---and at the same time shows her resistance to her own loneliness. She wants at once to extend and to limit, to see more of Bankes and less of 
herself. This conflict is represented in the simultaneous development of two registers: the succession of main clauses inscribing Lily's voice, and the little interruptions of the parentheses, at the corner of Lily's eye. The final set of brackets describes a sudden obstruction of her vision: the rising of potatoes before her eyes. Yet this obstruction too is part of the movement of her thought: it is her habit to conceptualize intellectual disciplines as material objects ("She always saw, when she thought of Mr. Ramsay's work, a scrubbed kitchen table.") (17) Obviously the parentheses help render the inner world of Lily more exactly clearly and help present us with the exact condition of consciousness. Sometimes Woolf puts her interior monologue also in the parentheses as displayed in the following passage:

'Such expeditions', said Mr. Ramsay, scraping the ground with his toe, 'are very painful.' Still Lily said nothing. (She is a stock, she is a stone, he said to himself.) 'They are very exhausting,' he said, looking, with a sickly look that nauseated her (he was acting, she felt, this great man was dramatizing himself) at his beautiful hands (To the Lighthouse, 114).

Here again the parentheses act as signals of perspective. They are the demarcation lines between omniscient narration and interior monologue. With the help of brackets, Woolf makes an easy and clear transition between the two. And this is one of the indications of her sophistication in artistry. With her unique devices such as guiding phrases, semicolons, and parentheses embroidered to her interior monologue, Virginia Woolf successfully overcomes the shortcomings of stream-of-consciousness novel of being incoherent and chaotic, and achieves great explicitness, coherence, vividness and surface unity in presenting the characters' inner world. However, it should be noted that her presentation of the characters' interior monologue is not only coherent in meaning, but also conventional in appearance. It is something of a shock to realize that what is usually considered the most extreme form of the experimental novel is often worked out with the basic method of using conventional description by an omniscient author--without any attempt on the part of the author to disguise the fact. The only thing unusual about it is the subject of this description, which, of course, in the stream-of-consciousness novel is the consciousness or psychic life of the characters.

\section{Conclusion}

Modern period has different styles of writing, using Interior monologue or stream of consciousness was the most important technique of this period. The term Interior monologue "stream of consciousness" refers to a narrative technique of writing in which the flow of thought, mind of the character and emotions reflected in the text directly and without any mediation of the author. Since the mind of an ordinary person is not fixed and jumps from one scene to another, the author attempts to present this phenomenon as it is. So it's a technique through which the author writes as if he is inside the mind of the narrator. This technique is applied by many novelists like James Joyce, Virginia Woolf and William Faulkner. Examples of this technique can be seen in Virginia Woolf's Mrs. Dalloway and To the Lighthouse, James Joyce's Ulysses, Katherine Porter's Flowering Judes, William Faulkner's The Sound and The Fury and Houshang Golshiri's Shazedh Ehtejab. Golshiri as one of the first Iranian writers who used modern literary techniques such as interior monologue "stream of consciousness"

One of the amazing things about Shazdeh Ehtejab is the creative use of time. The novel starts at night and ends in the morning. Shazdeh is sitting on his chair, his forehead is hot and he's coughing. By ending the story, readers find that the whole story was a memory, Shazdeh reviews his life during two or three minutes before his death. In the beginning of the story 
Morad and his wife are searching for Shazdeh in the alley and at the end of the story they announce Shazdeh's death. It seems Morad is the messenger of death. In these three novels the focus is on the sense of time and shows how the past time is fused with the present to make a new technique of presenting the story. It can be concluded that both novelists, Houshang Golshiri and Virginia Woolf made it possible for the reader to enter the character's mind through a frequent use of interior monologue. Provides the appropriate space for interchange between author, narrator, character and reader.

\section{References}

Basirizade, Fatemeh Sadat. (2019). A Comparative Study of the Psychoanalytical Portrayal of the Women Characters by Virginia Woolf and Zoya Pirzad. Britain International of Humanities and Social Sciences Journal, 1(1); 1-8.

Golshiri, Houshang. (2005). Shazdeh Ehtejab. Tehran: Niloufar Publication.

Keyhan, khojasteh. (2007). Khanoum Dalloway. Tehran: Negah Publication.

Lee, Hermione. (2010). The Novels of Virginia Woolf. New York: Routledge Taylor\& Francis Group.

Winston, Janet. (2009). Woolf's To the Lighthouse A Reader's Guide. New York: Continuum International Publishing Group,.

Woolf, Virginia. (2004). Mrs. Dalloway. New Delhi: UBS Publisher's Distributors Pvt.Ltd.

........ To the Lighthouse. (2006). New Delhi: UBS Publisher's Distributors Pvt.Ltd 